educated in Ireland, that Vanbrugh was of Flemish extraction, and Arbuthnot a Scotchman (i., 118). None of the Scotch writers mentioned by Dr. Fairbairn came into literature until a good while after Queen Anne. The isolated mention of Arbuthnot might surely have opened his eyes to the sufticiently obvious fact that I was occupied solely with the time when Collins's Discourse appesred. Not content with making mountains out of molehills he makes them out of valleys.

“Mr. Benn's account of 'Positive' and 'Positivism' is more popular than scientific. The term is to be understood through Roman Lar which opposed the $J_{12}$ Poritivum to the $J_{\text {its }}$ Naturale rather than through any analysis of the positive man." Dr. Fairbsirn must excuse ny saying that be is quite mistaken. He will admit, I hope, that Littri in his double capacity as a Contist and an etymologist knew something about the matter. I open his Dictionary at the word "positif"; I find it defined, to begin with, as "qui est essuré," then secondarily as "qui s'appuie sur les faits" ; and in this connexion he explains that Comte's philosophy is called " positive," as professing to emanste from the sciences that are based on facts. Then he specifies, as I have done, the use peculiar to French of positive as opposed to imaginative and ideal. Afterwards comes a quite distinct section explaining the legal use of "pusitif" opposed to "naturel," and here there is no reference to Positivism. Indeed so far is there from being an antithesis between " positive," in Comte's sense, and " natural," that Comte himself points out a considerable analogy between his philosophy and what the English since Newton understand as natural philosophy ; while Littré again in his Introduction compares Comte's classification of the Sciences to the natuml as distinguished from the artificial systems of botany and zoology. Thus Dr. Fairnbairn's etymological clue leads off on a falme track. If that is a specimen of his " scientific" method, I prefer being "popular".

Had such unfounded criticisms appenred anonymously in a weekly religious journal, they unight have been let puss unnoticed. Appearing in MiND under an authoritative sigmature they might damage my credit as a historian if I did not show on what sort of basis they rest.

Alfred W. Bens.

\title{
SOME REMARKS ON A RECENT FOOT-NOTE BY MR. BRADLEY.
}

In a foot-note on page 172 of the last number of Mind Mr. Bradley Ins to reiterate his forner claim (N.S., No. 65, p. 439) to have answered by anticipation, in his Appartance, my criticism (N.S., No. 54) of his doctrine of the "A bsolute Criterion". But he maintains a complete, if not unintelligible, silence in regard to the fact that in N.S., No. 37, page 141, he was challenged to produce " any passage or prossages in the pages he now refers to in which the main objection I have urged has been even so much as recognised ". In that short reply I further took the trouble of condensing the said objection as follows: "The gravamen of my criticism lay in this, that whereas Mr. Bradley had asserted that the principle of contradiction affords an absolute criterion for distinguishing appesance from reality, I pointed out that self-contradiction is only foreign to reality in so far as it is foreign to appestrance as such ".

To excuse one's self from directly answering an adverse criticisin by claining to have answered it already, and then, being exhurted to state 
how and where, to ignore the exhortation but repeat the claim-surely this is a strange manifestation of one's anxiety "to be of use to all the world"?

How

\section{MIND ASSOCIATION.}

The Eighth Annual General Meeting of the Association was held on 1st June, in Corpus Christi College, Oxford. The financial position of the Association was considered, officers were elected, and it was resolved that next year's meeting should be held at Cambridge in May or June.

The following have joined the Association since the printing of the lest number :-

Dyer (Mrs.), 68 Banbury Roed, Oxford.

Ross (G. R. T.), The Mount, Highfield Cresoent, Southampton.

Spencer (C. N.), Walden, Tatsfiold, Surrey.

Those who wish to join the Association should communicate with the Hon. Secretary, Mr. Henry Sturt, 5 Park Terrace, Oxford; or with the Hon. Treasurer, Dr. F. C. S. Schiller, Corpus Christi College, Oxford, to whom the yearly subscription of one guines should be paid.

Members resident in U.S.A. may, if they choose, pay their subscription (\$5) into the account of the Treasurer (Dr. F. C.S. ScHILlER) at the Fifth Avenue Bank, corner of 44th Street, New York, U.S.A 